\title{
Agnieszka Kurnik
}

Uniwersytet Papieski Jana Pawła II w Krakowie

\section{W POLU DOBRA I ZEA. KILKA UWAG O ROLI SOBOROWEGO DEKRETU INTER MIRIFICA}

\begin{abstract}
In the field of good and evil. A few remarks on the role of the Second Vatican Council's Decree on media of social communications Inter mirifica in the modern world. The article discusses the Decree on media of social communications Inter mirifica adopted 50 years ago by the Second Vatican Council as the second in the sequence of the Council's documents. The author pays special attention to the analysis of part I, focusing on the integral development of both media transmitters and media receivers as well as on the moral aspect of shaping good conscience in members of the media community, which particularly significant in the times of development and expansion of the internet.

Artykuł dotyczy Dekretu o środkach masowego przekazu Inter mirifica, uchwalonego 50 lat temu przez Sobór Watykański II jako drugi w kolejności dokument soborowy. Autorka analizuje zwłaszcza jego część I, obdarzając szczególną uwagą integralny rozwój tak nadawców, jak odbiorców medialnych oraz niezwykle istotny $\mathrm{w}$ dobie rozwoju i ekspansji internetu moralny aspekt kształtowania prawych sumień członków medialnej społeczności.
\end{abstract}

Keywords: Second Vatican Council, media, Inter mirifica, progress, conscience, morality, media Sobór Watykański II, media, Inter mirifica, postęp, sumienie, moralność, media

4 grudnia 2013 roku przypadła 50. rocznica uchwalenia Dekretu o środkach masowego przekazu Inter mirifica. Był on chronologicznie drugim po konstytucji o liturgii świętej dokumentem soborowym ${ }^{1}$. Biorąc pod uwagę czas zakończenia soboru, zwraca uwagę stosunkowo wczesne opracowanie i przyjęcie omawianego dokumentu. $\mathrm{Z}$ perspektywy półwiecza warto i trzeba zarazem zastanowić się, które z uwag w nim

\footnotetext{
1 Bp A. Lepa, Wprowadzenie do Dekretu o środkach społecznego przekazu, [w:] Sobór Watykański Drugi. Konstytucje, dekrety, deklaracje: tekst polski, nowe tłumaczenie, red. M. Przybył, Poznań 2002, s. 82.
} 
zawartych wywarły - i winny w dalszym ciągu wywierać największy wpływ na kształt mediów tak w ostatnim 50-leciu, jak i współcześnie. Dokument, mimo upływu lat nadzwyczaj aktualny, wciąż inspiruje bowiem tak duchownych, jak i świeckich związanych zawodowo $\mathrm{z}$ mediami do dalszych pogłębionych analiz i fachowych prac badawczych.

Zanim jednak poddamy - z konieczności wąsko ukierunkowanej - analizie sam kształt i treść dokumentu, spójrzmy choćby przez chwilę na obraz dyskusji soborowych toczących się wokół niniejszego dekretu i jego zawartości. Jak stwierdza we wprowadzeniu do dekretu bp Adam Lepa, „pracom, które prowadzono nad projektem [...] towarzyszyły liczne dyskusje"2. Ich istotę stanowiła różnica zapatrywań co do zawartych w nim treści, jak też co do koncepcji i kształtu samego dokumentu. Niektórzy z dyskutantów, odnosząc się do świata mediów krytycznie, zgłaszali postulaty radykalnych ocen ówczesnej sytuacji. Inni z kolei byli zdania, że należy ograniczyć wymiar problematyki moralnej przy jednoczesnym pogłębieniu teologicznego wymiaru dekretu. Istniały również stanowiska postulujące ograniczenie eklezjalnego charakteru dokumentu, ze szczególnym uwzględnieniem i naciskiem traktujące role osób świeckich w tym dziele, ich prawa i obowiązki. Biorąc pod uwagę powszechny wymiar działalności Kościoła, przy całym zróżnicowaniu sytuacji społeczno-politycznej tego okresu, a także coraz wyraźniej zaznaczającego się wpływu na media świata polityki i biznesu, przyjęto ostatecznie formułę integralnie traktującą sam przedmiot dyskursu przy jednoczesnym pominięciu teologicznej egzemplifikacji zagadnienia ${ }^{3}$. Cytowany przez bpa Adama Lepę kard. Andrzej Maria Deskur we wprowadzeniu do dekretu pochodzącym z pierwszego (poznańskiego) wydania dokumentów soborowych podkreślił wyraźnie „umiarkowanie i rozwagę, cechujące całość przyjętej wersji ostatecznej dekretu ${ }^{4}$. Brak jednoznacznego wskazania na negatywne zjawiska występujące w obrębie świata mediów w żadnym razie nie był ze strony ojców soborowych próbą uniku w tej materii. Najlepszym na to dowodem jest zredagowana na wyraźne polecenie Vaticanum II, a sygnalizowana w Inter mirifica instrukcja duszpasterska Communio et progressio pochodząca z 1971 roku, a także późniejsza Aetatis novae, wydana w roku $1992^{5}$. Co jednak za bpem Lepą warto podkreślić, po encyklikach papieży: Vigilanti cura Piusa XI (1936) i Miranda prorsus Piusa XII (1957) dokument ten był pierwszą próbą całościowego zmierzenia się Kościoła z rozkwitającymi pod wpływem postępu medialnego nowymi typami kontaktów nadawczo-odbiorczych, a także z wyzwaniami przez owe kontakty niesionymi. Szczególnie istotna była powszechność medialnego przekazu, zwłaszcza zaś wynalazek telewizji, która, podobnie jak kino, stawała się coraz częściej ekspansywną „tubą informacyjną” i „oknem na świat”. Wprawdzie pierwszy raz terminu „telewizja” użyto w roku 1900 na światowej wystawie w Paryżu, niemniej dopiero 50 lat później kontynuowane w USA prace w zakresie przekazywania obrazu na odległość były tak dalece zaawansowane, iż umożliwiały jego emisję w kolorze. Początek lat 60. to czas wprowadzenia we Francji systemu Secam (1961) (przyjętego także w Polsce pod koniec dekady) i systemu PAL w Niemczech Zachodnich (1963). Także telewizja w Polsce, podejmująca próby z wykorzystaniem obrazu stosunkowo wcześnie (rok 1937), po latach powojennych doświadczeń kontynuowała

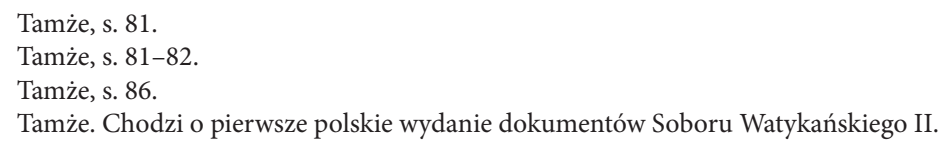


fazę eksperymentalną, zwieńczoną nadawaniem stałych programów $(1956)^{6}$. Zmiana mentalna była zatem uwarunkowana postępującą zmianą o charakterze kulturowo-cywilizacyjnym, a tym samym coraz wyraźniejszym rozluźnieniem rygorów moralno-obyczajowych. Wszystkie te czynniki, powiązane ze stałym wzrostem zainteresowania prasą drukowaną, kinematografią i radiofonią - a także dysproporcjami rozwojowymi prasy w państwach zachodnich i krajach pozostających pod wpływem opresji sowieckiej - stwarzały nowy, ważny kontekst, do którego Sobór w zaistniałych warunkach musiał się odnieść. Co więcej, jak pisze w słowie wprowadzającym do dekretu bp Adam Lepa, istniało źródło dodatkowe, domagające się szczegółowej egzemplifikacji i interpretacji. Źródłem tym była adhortacja apostolska papieża Pawła VI Evangelii nuntiandi, w której ojciec święty cywilizacji słowa przeciwstawił wprost cywilizację obrazu (EN 42). Ważne było zatem wskazanie na otwartą perspektywę cywilizacyjno-formacyjną, wynikającą z istnienia nowych, technicznych środków wyrazu i powojennej sytuacji, do której to formacji dokument soborowy, nie odnosząc się wprost do istniejących wówczas społeczno-politycznych uwarunkowań, jednocześnie bezpośrednio zachęca.

Warto jednak, choćby naskórkowo, nawiązać do dwóch encyklik podejmujących bezpośrednio temat mediów, których ekspansywny rozwój był stale obserwowany i monitorowany przez Stolicę Apostolską. Mający szczególne zasługi w tym zakresie papież Pius XI ogłosił wszak swą encyklikę Vigilanti cura już 29 czerwca 1936 roku. Katarzyna Pokorna-Ignatowicz dostrzega w niej „chęć podporządkowania filmu etyce chrześcijańskiej"”. Nie tyle chodzi tu jednak o podporządkowanie, ile o formację tak nadawców, jak odbiorców filmowego dzieła. Odpowiednio ukształtowane sumienie będzie się bowiem wzdragać przed sięgnięciem po środki niemoralne, wywołujące publiczne zgorszenie i bezwstyd. Warto tu z kolei podkreślić roztropność i przezorność wobec sił zła drugiej z encyklik, Miranda prorsus (1957) autorstwa Piusa XII, traktującej problem mediów komplementarnie. W wypowiedzi ojca świętego zwraca uwagę zwłaszcza wskazanie na samego człowieka jako źródło zła - ze szczególnym uwzględnieniem działań władzy politycznej, z pragmatycznych względów uchylającej się przed właściwą reakcją na poczynania deprawatorów i obroną publicznej moralności. Kolejnym ważnym aspektem sprawy, zasługującym na szersze rozważenie, jest podnoszony często w środowiskach artystycznych problem tzw. nieskrępowanej ekspresji artystycznej. Twórcy niestosujący się do prawa Bożego i naturalnego i nieuznający moralności chrześcijańskiej są bowiem zdania, że mają prawo wyrażać swoje poglądy publicznie bez jakichkolwiek ograniczeń i przeszkód. Pius XII umiejętnie odpiera zarzut, tłumacząc, że byłoby tak istotnie, gdyby rzekoma „opresja” odnosiła się do życia prywatnego tych osób. Ponieważ jednak jest tu mowa o funkcji społecznej, jaką jest rozpowszechnianie utworów artystycznych - zarzut nie powinien być podnoszony. Pozostawianie tych kwestii odłogiem przyczynia się wszak do duchowego i moralnego upadku narodów i społeczeństw, a na to żadna szanująca się władza państwowa i kościelna nie może - i nie powinna dawać przyzwolenia.

W encyklice pojawiają się także uwagi krytyczne, wskazujące na obecne już wówczas w przestrzeni medialnej próby rugowania z przekazu recenzenckiego jakichkolwiek odniesień do spraw moralności. Nie ulega jednak wątpliwości, że w centrum przekazu ojców soborowych stoi nieodmiennie norma personalistyczna, streszczająca

6 Zob. Z. Bajka, Historia mediów, Kraków 2008, s. 194-199.

7 K. Pokorna-Ignatowicz, Kościół w świecie mediów: historia, dokumenty, dylematy, Kraków 2002, s. 40-41. 
się w przykazaniu miłości, nakazująca piętnowanie zła, nie zaś potępianie grzeszników. W tym duchu zatem Inter mirifica zwraca się do wszystkich ludzi dobrej woli, na pierwszym miejscu stawiając dobro płynące ze wzajemnej współpracy i troski o kształt teraźniejszości i przyszłości.

Nie dokonując zatem partykularnej oceny działalności poszczególnych mediów, dekret wyraźnie zaznacza szczególne znaczenie wszystkich spośród nich w dziele budowy i rozpowszechniania Królestwa Bożego. Co ważne, a co było już wzmiankowane, ojcowie soborowi nie zamykają oczu na zło sączące się z przekazu medialnego. Formy zła nie zostają wprawdzie wymienione wprost, niemniej nie należy tego typu pominięć traktować jako rodzaju krótkowzroczności. Uważny czytelnik wspomnianego dokumentu odnajdzie bowiem już w drugim akapicie Wstępu ważne słowa:

Matka Kościół ma świadomość, iż o ile te środki zostaną wykorzystane w sposób właściwy, mogą przynieść rodzajowi ludzkiemu skuteczną pomoc [...]. Zdaje sobie jednak również sprawę z tego, że ludzie mogą ich użyć wbrew zamysłowi Boskiego Stwórcy i obrócić na swą własną niekorzyść. Kościół odczuwa macierzyński ból z powodu szkód, jakich wskutek niewłaściwego ich użycia często doznaje ludzka społeczność. Dlatego Święty Sobór, podejmując w tak ważnej sprawie pełną uwagi troskę papieży i biskupów, uznaje, że spoczywa na nim obowiązek rozpatrzenia najważniejszych zagadnień związanych ze środkami społecznego przekazu. Ufa ponadto, że jego nauka i wymagania ukazane w ten sposób przyczynią się nie tylko do zbawienia chrześcijan, ale i do postępu całej wspólnoty ludzkiej (IM 2).

Jednym z najważniejszych pojęć pojawiających się tak w dekrecie, jak i w innych dokumentach soboru jest cytowane przed momentem pojęcie postępu, będące integralną częścią tak konstytucji, jak i innych aktów soborowych. Znaczenie słowa „postęp”, użytego w poprzednim akapicie dość często interpretuje się w świetle świeckiego, laickiego humanizmu, niewiele mającego wspólnego z założeniami myśli soborowej. Istnieje tutaj zasadnicze nieporozumienie, które domaga się rozjaśnienia - tak w perspektywie chrześcijańskiej, jak i ogólnoludzkiej. Sobór, jak to wynika z jego dokumentów, a także z Inter mirifica, nazywa postępem integralny (duchowy, intelektualny i materialny) rozwój człowieka i całej ludzkości, co więcej: rozwój w mądry sposób zmierzający do czynienia sobie ziemi poddaną. Tym samym postęp jest równoznaczny z pomnażaniem dobra, służącego bez wyjątku każdej istocie ludzkiej - a zatem także całemu światu. Taki postęp może się dokonywać tylko wówczas, gdy zachowane zostaje prawo moralne, zaś każdy człowiek (a chrześcijanin w szczególności) transcenduje się w zamyśle czynienia dobra i unikania zła. Tylko pod tym warunkiem jest możliwe twórcze, a zarazem dobre wykorzystanie środków technicznych i cywilizacyjnych wraz z ich nowymi odmianami w dziele tworzenia kultury oraz przekazu informacji i jej wykorzystania (współcześnie odnosi się to także m.in. do internetu i cyfrowego przekazu telewizyjnego). Czy nie jest to stwierdzenie tożsame w pewnej mierze ze stwierdzeniem wypowiedzianym przed laty przez Jana Pawła II podczas rozmowy z André Frossardem? „Kultura [...] oznacza dążenie do świata, w którym człowiek realizuje swe człowieczeństwo we właściwej mu transcendencji: przez odniesienie do prawdy, dobra i piękna”8. Jednocześnie w tej per-

8 A. Frossard, „Nie lękajcie się!”, Rozmowy z Janem Pawłem II, przekł. A. Turowiczowa, Citta del Vaticano 1982, s. 258, za: K. Klauza, Kultura przestrzenią dialogu Kościoła ze światem po Vaticanum Secundum, „Ethos” 
spektywie warto pamiętać, że o ile kultura jest stałą drogą tworzenia nowej rzeczywistości, o tyle rola nasza w tym procesie ma być rolą ciągłej współpracy ze stwórczą mocą Boga, także w perspektywie odpowiedzialności za własne czyny i działania związane z pracą w mediach. „Nie wolno nam oddzielać naszego zawodu od życia religijnego. Chrześcijanin, który zaniedbuje swoje ziemskie obowiązki, zaniedbuje również miłość do Boga i miłość bliźniego. Wiara nie odciąga człowieka od jego zadań wobec świata, ona go do nich zobowiązuje" . Istotą tego zobowiązania jest powołanie chrześcijańskie, które, jak powiada Jan Paweł II w encyklice Redemptor hominis, obejmuje wszystkich członków Kościoła, Mistycznego Ciała Chrystusa.

Jest to właśnie zasada owej „królewskiej służby”, która każdemu z nas nakazuje za wzorem Chrystusa wymagać od siebie; wymagać właśnie tego, do czego jesteśmy powołani i do czego, przyjmując powołanie, sami zobowiązaliśmy się z łaską Bożą. Taka wierność powołaniu otrzymanemu przez Chrystusa od Boga niesie z sobą ową solidarną odpowiedzialność za Kościól, do której Sobór Watykański II chce wychowywać wszystkich chrześcijan. [...] W naszych czasach nieraz błędnie się mniema, że wolność sama jest dla siebie celem, że człowiek jest wolny, kiedy jej używa w jakikolwiek sposób, że do tego należy dążyć w życiu jednostek i społeczeństw. Tymczasem wolność jest wielkim dobrem wówczas, kiedy umiemy świadomie jej używać dla tego wszystkiego, co jest prawdziwym dobrem. Chrystus uczy nas, że najwspanialszym wypełnieniem wolności jest miłość, która urzeczywistnia się w oddaniu i służbie (RH 21).

Tylko w tej perspektywie i pod tym warunkiem media, zaś w szczególności media katolickie będą mogły rozkwitać, w pełni służąc Prawdzie, Dobru i Pięknu.

Jednym z koniecznych warunków tworzenia przez chrześcijan dobrych mediów jest zatem stanięcie w prawdzie własnego życia, dokonywanych wyborów i wzajemnych międzyludzkich relacji. Co zaś najważniejsze - przywoływana w dokumencie konieczność kształtowania prawego sumienia - nie bez znaczenia zwłaszcza w dzisiejszych czasach, z racji nieustannie toczonych społecznych sporów. Dziennikarz, dla którego chrześcijaństwo stanowi treść życia, będzie się zatem starał wszelkimi dostępnymi środkami utwierdzać w swych odbiorcach zręby cywilizacji miłości - czy to poprzez przekaz prasowy, telewizyjny, czy internetowy. Nie można oddzielać wiary od życia, byłoby to zaprzeczeniem naszej chrześcijańskiej tożsamości. W spluralizowanym świecie powstaje niejednokrotnie wrażenie, że sumienia można naginać w zależności od okoliczności, zaś istnienie prawdy obiektywnej jest rodzajem kontrolowanego złudzenia. Dekret Inter mirifica utwierdza nas w przekonaniu, że jest dokładnie odwrotnie. Sumienie ma podlegać nieustannemu kształtowaniu ku prawości, zaś istnienie obiektywnej prawdy to sprawa bezsporna, co więcej - bezcenna w dziele mającej aktualnie miejsce nowej ewangelizacji.

Ze sprawą porządku moralnego i ukształtowanej prawości sumienia wiąże się kolejny aspekt, wyraźnie zaznaczony w dokumencie. Jest nim prawo do rzetelnej informacji o rzeczywistości, która nas otacza. Pojawiają się tu także stwierdzenia o godziwości i stosowności informacji przekazywanych we wszelakich mediach. Równocześnie jest

2012, nr 4 (100), s. 113. O relacji Jana Pawła II do świata mediów zob. A. Baczyński, M. Drożdż, Nie lękajcie się. Jan Paweł II i media, Kraków 2011.

9 F. Krenzer, Taka jest nasza wiara, Paryż 1981, s. 261. 
tu mowa o poszanowaniu godności każdego człowieka w zakresie tak publikowania, jak gromadzenia informacji. Ojcowie soborowi zwracają zatem wyraźnie uwagę na rolę formacyjną prawdy, a także pośrednio na normę personalistyczną, która streszcza się w przykazaniu miłości. Zbyt częste poszukiwanie sensacji, publikowanie wiadomości niesprawdzonych, a szkalujących konkretne osoby, rozpowszechnianie drastycznych zdjęć osób bez ich wiedzy i zgody, ujawnianie treści niszczących pod względem moralnym, nieprzeznaczonych dla szerokiego odbiorcy - to tylko niektóre z grzechów współczesnego dziennikarstwa przeciwko temu przykazaniu. Celuje w tym procederze zwłaszcza prasa brukowa, odwołująca się do szerokiego kręgu społecznego, preferująca styl obraźliwie plotkarski, niecofająca się przed fałszywymi oskarżeniami o popełnianie przestępstw, ferująca wyroki jeszcze przed ich ogłoszeniem - i degenerująca podstawy zdrowego bytu społecznego. Wtórują jej podobnie nacechowane portale internetowe, których jedynym zadaniem jest podsycanie niezdrowych emocji, przekaz wulgarnych treści erotycznych bądź bulwersowanie perwersjami najrozmaitszej natury. Co więcej, tego rodzaju zagrożenie przenika także do mediów o charakterze informacyjnym czy tygodników opinii. Tymczasem dziennikarz będący jednocześnie chrześcijaninem musi wytrwale świadczyć o własnej wierze, a jeśli tego potrzeba - być jej nieustraszonym obrońcą. Istnieje dziś szczególne zapotrzebowanie na ludzi mediów, którzy wezmą sobie do serca wypowiedziane przez Jana Pawła II w Skoczowie ważne, a często zapominane słowa: „Polska woła dzisiaj o ludzi sumienia!”.

Jeśli jednak obowiązek kształtowania sumień w duchu prawości spoczywa na nadawcach medialnych - równie istotna rola przypada odbiorcom poszczególnych treści. O tym, jak ważna jest to rola, przypomina zawarty w dekrecie postulat właściwego wyboru. Tak czytelnicy, jak widzowie i słuchacze mają bowiem w tym względzie obowiązek wyboru tych spośród treści, które wyraźnie wyróżniają się „z moralnego, naukowego lub artystycznego punktu widzenia” (IM 9). Gdy mówimy o wyróżnianiu się, bierzemy pod uwagę to wszystko, co przynosi człowiekowi korzyść w sferze duchowej. Trzeba tu pamiętać, że zło przychodzi często pod pozorem dobra, stanowi rodzaj pokusy, której nieprzygotowanym do odpowiedniego odbioru tych treści łatwo ulec. Dotyczy to szczególnie osób niedojrzałych - tak duchowo, jak i wiekowo, stąd ważny postulat ochrony dzieci i młodzieży przed treściami mogącymi uczynić szkody w ich wrażliwych umysłach i sercach. Dekret wzmacnia tu znacząco rolę rodziców jako pierwszych nauczycieli młodocianych (IM 10). Wyeksponowana zostaje rola nauczycieli, wychowawców i specjalistów, którzy winni wspierać rodziców, służąc im pomocą w ich trudnym zadaniu. Media - tak publiczne, jak komercyjne - coraz częściej nastawione na łatwy zysk, są w stanie za pomocą szczególnych środków wpływać na zmysły nieprzygotowanych odbiorców. Specjalna rola w tym względzie niewątpliwie przypada przekazowi reklamowemu, manipulacyjnemu i propagandowemu, o którego niechlubnej roli bardzo wiele już powiedziano ${ }^{10}$.

Kolejna kwestia, której wagi nie sposób przecenić, to wspomniana już sfera relacji między prawami sztuki a normami prawa moralnego (IM 6). Rzecz dotyczy szeroko pojętej sztuki i literatury, ze szczególnym uwzględnieniem dramaturgii. Treści obraźliwe i obrazoburcze, sprzeczne z prawem moralnym, będące częścią działalności artystycznej

10 Zob. M. Iłowiecki, Media. Władza. Świadomość społeczna, Kraków 1997; P. Legutko, D. Rodziewicz, Mity czwartej władzy dla widzów, słuchaczy i czytaczy, Kraków 2002. 
i literackiej, przedstawiane w świetle pozytywnym wywołują zamęt wśród rozlicznych odbiorców. Jeszcze większy zamęt tworzy kreowanie na autorytety członków artystycznych społeczności - kontestujących prawo moralne lub wręcz je negujących. Zapraszanie takich osób do telewizji, by przedstawiać ich postępowanie jako godne pochwały, promowanie wszelkich przejawów zła przez nie reprezentowanych - to kolejny przejaw walki dobra ze złem, która toczy się tak długo, jak długo istnieje świat. Warto wspomnieć za dekretem, że budzące tyle emocji kontrowersje „wywodzą się z fałszywych doktryn etycznych i estetycznych”. Uczciwe media powinny zatem dać możliwość wypowiedzenia się specjalistom, którzy naświetlając odpowiednio kontekst i przyczyny nagłaśniania fałszu, przedstawią rzecz we właściwej perspektywie. Jednak jak widać, biorące górę w przekazie medialnym nurty libertyńskie i tu dokonują rozlicznych manipulacji. Daleko im pod tym względem do choćby pozorów obiektywizmu. Trudno się zatem dziwić stanowczym odmowom zapraszanych do programu specjalistów, gdy jednocześnie w studiu gości się inne osoby, mające zdyskredytować dorobek ekspercki oponenta bądź wyśmiać „zaściankowość” rzekomo „fideistycznych” przekonań. Zauważmy jednak, że oponenci owych ekspertów z reguły wyrażają interes pewnych izolowanych grup, nagłośnionych w postmodernistycznej atmosferze dochodzenia do głosu mniejszości. Grupom tym z racji odwołań do błędnych przekonań ideologicznych permanentnie brakuje całościowej wizji świata - tak przeszłości, jak teraźniejszości i przyszłości. Natomiast chrześcijanin widzi rzeczywistość z perspektywy integralnej, całościowej. Jego horyzont nie zamyka się w obrębie jakiegoś „tu i teraz”, jest zawsze wychylony w stronę wieczności. To zasadniczo zmienia punkt widzenia na świat i rzeczywistość. Widząc zło, chrześcijanin czuje w sobie głęboką powinność przeciwstawiania się mu z użyciem - by tak rzec - Bożej logiki. Nie przez przypadek bowiem błogosławiony ksiądz Jerzy Popiełuszko powiada za św. Pawłem: „Nie daj się zwyciężyć złu, ale zło dobrem zwyciężaj”. Tą samą zasadą, aktualną jako powinność od czasów Chrystusa winny kierować się media. Im więcej dobra - a zatem: szacunku dla człowieczeństwa, wrażliwości, delikatności, artyzmu, wywołującego pragnienie urzeczywistniania wartości - tym mniej przemocy, zła, gwałtu, występku i niesprawiedliwości. Do takiej „pracy nad pracą” zobowiązuje w rozdziale II dekret Inter mirifica:

Wszystkie dzieci Kościoła powinny jednomyślnie i zgodnie czynić wysiłki, aby środki społecznego przekazu bezzwłocznie były używane z największą rozwagą i skutecznością $\mathrm{w}$ rozlicznych zadaniach apostolskich, stosownie do wymogów czasu i okoliczności, w celu zapobiegania szkodliwym przedsięwzięciom, w tych zwłaszcza miejscach, w których moralny i religijny rozwój wymaga bardziej intensywnego wysiłku (IM 13).

Do tego rodzaju pracy powołani są tak pasterze Kościoła, jak i ludzie mediów, których powinnością jest wspieranie pasterskiej misji Kościoła tak w sferze technicznej i ekonomicznej - jak i na płaszczyźnie działalności kulturalnej, ze szczególnym uwzględnieniem form artystycznych. Na podkreślenie zasługuje także troska ojców soboru o klasyczne formy teatralne - i docenienie roli, jaką spełniały i spełniają w dziele kształtowania kultury i obyczajów odbiorców. Również kino jako ważne medium zasłużyło na parę słów uwagi. W jednym z akapitów dekretu ojcowie wyraźnie przypominają o obowiązku wsparcia i zabezpieczenia produkcji i rozpowszechniania oraz nagradzania filmów służących „godziwej rozrywce, rozwojowi kulturalnemu i artystycznemu” (IM 14). Nic 
zatem dziwnego, że to młodzież, nadzieja na przyszłość świata jest tu wymieniana jako szczególny adresat przekazu filmowego. Doceniono w tej materii także rolę radia i telewizji, ze szczególnym podkreśleniem audycji katolickich, służących wzrostowi duchowemu rodzin. Pojawia się także postulat - aktualny i realizowany współcześnie - tworzenia przez Kościół stacji radiowych i telewizyjnych o jak najszerszym zakresie oddziaływania (IM 14), z jednoczesną troską o wysoki poziom merytoryczny prezentowanych audycji. Nie do przecenienia jest bowiem rola mediów w zakresie formowania jednostek i społeczności, przekazu wartości chrześcijańskich, promowania dobra moralnego. Skoro zaś o tym mowa - przychodzi czas na postulat szerokiego kształcenia dziennikarzy, twórców filmów, redaktorów filmowych i telewizyjnych, specjalistów w zakresie krytyki artystycznej i teatralnej czy wreszcie artystów, którzy umiejętnie operując słowem, gestem i postawą, przyczynialiby się do ukazywania racji moralnych, jak precyzuje to dokument, „we właściwym świetle” (IM 15).

Szczególnie ostatni z postulatów ma dziś olbrzymią moc i zasadność. Wielu nadawców publicznych i komercyjnych przekonało nas wielokrotnie, że w ich optyce racja moralna stoi często na drugim planie. Górę biorą względy utylitarne, liczy się oglądalność i zysk z tego tytułu. Media, które winny pełnić misję publiczną, powinny „zyskiwać” w inny sposób, grupując grono życzliwych odbiorców, rozumiejących, jak cenny jest wkład pracy podejmowanej dla wspólnego dobra. Jak zatem widzimy - jedynie dobrze uformowani ludzie, ludzie prawego sumienia są w stanie tworzyć dobre audycje i programy, przeznaczone dla szerokich rzesz odbiorców. Wystarczy bowiem jeden zgniły owoc złej formacji, by zaburzyć delikatną równowagę między nadawcą a odbiorcą. Nie możemy zapominać, że i tu wytwarza się pewna nić porozumienia, nić, którą przez tego typu nieodpowiedzialne praktyki bardzo łatwo nadwątlić lub zerwać.

Jak jednak wiadomo, dość często przyczyną niezaistnienia pewnego dobra jest brak środków finansowych. Ojcowie soboru usilnie apelują zatem do wszystkich ludzi dobrej woli, w szczególności jednak do „dzieci Kościoła”, o wsparcie wszelkich inicjatyw medialnych służących szerokiej sprawie - tak apostolstwa, jak szerzenia kultury prawdziwie chrześcijańskiej. Tej inicjatywie służy także ustanowienie światowego dnia środków społecznego przekazu - ze specjalną zbiórką pieniędzy na ten cel - i nareszcie kształtowanie świadomości wszelkich narodów i społeczeństw w tym zakresie - wzmocnione obecnością ciał kolegialnych złożonych z osób duchownych i świeckich, tak w perspektywach krajowych, jak i międzynarodowych. Zadanie kształtowania świadomości wiernych pozostaje nieustannym zadaniem wszystkich uważnych czytelników dekretu (IM II 17-22).

Współczesna kultura polska jest kulturą specyficznie „techniczną”, tj. uwarunkowaną uprzemysłowieniem i utechnicznieniem kraju; wpływ tych zjawisk jest silniejszy niekiedy niż oddziaływanie ideologii. I rządzący, i rządzeni w Polsce pozostają pod przemożnym urokiem techniki. [...] Człowieka "technicznego" cechuje optymizm wobec świata, wobec którego chrześcijaństwo bywało raczej nastawione krytycznie, naiwny racjonalizm - „zanik” - jak powiedziano w konstytucji Gaudium et spes Soboru Watykańskiego Drugiego - „zmysłu kontemplacji i podziwu”, lekceważenie wartości niewymiernych, religii, poezji, wszelkiego rodzaju imponderabiliów, przy równoczesnym afirmowaniu ciasno pojętej empirii. Kultura masowa, w której wedle znanego aforyzmu McLuhana „środek przekazu jest przekazem”, stała się procesem wytwarzania i konsumowania produktów kulturowych, które stanęły między twórcą a odbiorcą, sprawiając, że kultura jest w znacznie mniejszym stopniu niż 
dawniej spotkaniem międzyosobowym. [...] Nasze stulecie jest wiekiem reprodukcji mechanicznej, wykonywanej na skalę przemysłową: nie tylko książki, ale i reprodukcje, płyty, taśmy stały się czynnikiem decydującym o związku kultury współczesnej z jej technicznymi mediami

- powiada ks. Janusz Stanisław Pasierb o wieku XX w swej znanej książce Światło i só $l^{11}$. Twierdzenia te można by rozciągnąć na całą kulturę współczesną, coraz mocniej związaną z przemysłowym tokiem myślenia i funkcjonowania. Odnosi się to zwłaszcza do „produkowania” nadmiaru wątpliwych „autorytetów medialnych”, mających przemożny, z reguły negatywny wpływ na nasz sposób myślenia i działania. Dekret Inter mirifica zachęca nas do wyrwania się z „technokratycznego” marazmu i podjęcia służby dla wspólnego dobra. Potraktujmy go jak szczególny dar i przesłanie na następne dziesięciolecia XXI wieku.

\section{Bibliografia}

Baczyński A., Drożdż M., Nie lękajcie się. Jan Paweł II i media, Kraków 2011.

Bajka Z., Historia mediów, Kraków 2008.

Buttiglione R., Sobór Watykański II. Tradycja i wspótczesność, „Ethos” 2012, nr 4 (100), s. 27-51.

Dekret o środkach społecznego przekazu Inter mirifica, [w:] Sobór Watykański II. Konstytucje, dekrety, deklaracje: tekst polski, nowe tłumaczenie, wyd. 1, Poznań 2002, s. 87-95.

Encykliki Ojca Świętego bł. Jana Pawła II. Kompletne wydanie. Pamiątka beatyfikacji, Kraków 2011. Frossard A., „Nie lękajcie się!”. Rozmowy z Janem Pawłem II, przekł. A. Turowiczowa, Citta del Vaticano 1982.

Iłowiecki M., Media. Władza. Świadomość społeczna, Kraków 1997.

Klauza K., Kultura przestrzenia dialogu ze światem po Vaticanum Secundum, „Ethos” 2012, nr 4 (100), s. 101-117.

Krenzer F., Taka jest nasza wiara, Paris 1981.

Legutko P., Rodziewicz D., Mity czwartej władzy dla widzów, słuchaczy i czytaczy, Kraków 2002.

Lepa A., Wprowadzenie do Dekretu o środkach społecznego przekazu, [w:] Sobór Watykański II. Konstytucje, dekrety, deklaracje: tekst polski, nowe tłumaczenie, wyd. 1, Poznań 2002, s. 81-86.

Pasierb J. S., Światło i sól, Paryż 1983.

Paweł VI, adhort. apost. Evangelii nuntiandi.

Pius XI, enc. Vigilanti cura.

Pius XII, enc. Miranda prorsus.

Pokorna-Ignatowicz K., Kościół w świecie mediów: historia, dokumenty, dylematy, Kraków 2002.

Sobór Watykański II. Konstytucje, dekrety, deklaracje: tekst polski, wyd. 1, Poznań 1968.

Sobór Watykański II. Konstytucje, dekrety, deklaracje: tekst polski, nowe tłumaczenie, wyd. 1, Poznań 2002.

11 J. S. Pasierb, Światto i sól, Paryż 1983, s. 53. 